\title{
Career Management Practices: Impact of Work Design on Employee Retention
}

\author{
Ngirande Hlanganipai \\ Department of Business Management, University of Limpopo (Turfloop Campus), \\ Private Bag 1106. Sovenga, 0727. South Africa \\ E-mail: hlanganipai@yahoo.coml \\ Musara Mazanai \\ School of Business and Economics, Monash South Africa \\ (A campus of Monash University Australia), 144 Peter Rd, Ruimsig \\ E-mail: jilgram@yahoo.com
}

\section{Doi:10.5901/mjss.2014.v5n4p21}

\section{Abstract}

The paper presents the findings of the study that was conducted to investigate the impact of Work design on employee retention. A quantitative research methodology was used and 116 randomly selected respondents participated in this study. Self-administered questionnaires were administered to respondents; drawn from Manufacturing, Wholesale and Retail, Banking and Finance and Others industries. The data collected was analysed using SPSS 20.0. Correlational statistics revealed statistically significant relationship between all the ten (10) identified work design variables and employee retention variables. However strong correlations were observed between job enrichment, job design and job enlargement. Therefore, it can be recommended that addressing job enrichment; job design and job enlargement should take priority over others, if the organisation is to achieve acceptable employee retention levels. The value of the findings of this study lies in the explanatory utility of the identified relationships between work design variables and employee retention, in the 21st century economy whose main characteristics is high volatility in the work environment and high levels of employee mobility.

Keywords: Career management, Work Design, Employee Retention, South Africa.

\section{Introduction and Background}

Recently the topic of career management and employee retention has dominated research interests among human resources experts and academics. Continuous changes in the global economy have seen rising levels of work and career related uncertainties resulting in high labour mobility, restructuring and transformation in the workplace (Maree, 2012; Andersen, Haahr, Hansen and Holm-Pedersen, 2008; Huws \& Ramioul, 2006; Kalleberg, 2003). Under such conditions endeavours to come up with sound and sustainable career management practices to reduce labour mobility becomes imminent. This is owing to the fact that the human resource is the most important resource compared with other resources like machine, material, land, etc. in the organization context (Erasmus, Loedolff, Mda \& Nel, 2013); their welfare and effectiveness are a major determinant to the organisation's success.

Research indicates that satisfied employees due to good career management practices tend to be committed to an organization (Cooper-Hakim \& Viswesvaran, 2005), and employees who are satisfied and committed are more likely to stay with the organization (retention). Employee retention according to Coetzee and Schreuder (2012) refers to initiatives taken by management to keep employees from leaving the organization, such as rewarding employees for performing their jobs effectively; ensuring harmonious working relations between employees and managers; and maintaining a safe, healthy work environment. Employees' retention is crucial to the organisation's success, therefore organizations need to take cognisance of the changing priorities of job candidates as well as what attracts candidates to jobs and organizations (Redman \& Wilikinson, 2009). Consequently, an analysis of organisations' work design practices and their impact on employee retention with the aim of coming with solutions to the increasing employee turnover among many organisations in South Africa is imminent. In the view of the researchers, most of the employees face problems when their roles are periodically and this becomes complex because of ever changing industrial environments due to global competition among industries. These changes highly impact on employees' satisfaction and their retention. So, these issues are to be studied empirically. 


\section{Career Management Practices: A Focus on Work Design}

There are very few studies carried out in South Africa in respect of the impact of work design on employee retention. A research carried out by Mostafa (2012) focused on the impact of job satisfaction on employee retention. Another research carried out by Mam and Mace (2010) focused on the impact of job design on employees' performance. Another research done by Gialuisi (2012) focused on Voluntary employee turnover and retention practices. There is a little empirical evidence pointing at the relationship between work design and employees' retention, particularly in the developing nations, South Africa included (Cappelli, 2000; Cole 2000; and Accenture, 2001). Further a research carried out by Riyasa (2008) focused on 'Impact of job design on Employee's Satisfaction'. So it is possible to note that very few studies were carried out on job design in relation to employee retention especially in the wholesale \& retail and banking sector in South Africa.

It seems that there is a gap in this knowledge about testing the relationship between work design and employees' retention. Therefore the study seeks to investigate the effectiveness of employees' work design, the degree of employees' retention; investigate whether work design significantly relates to employees' retention among employees in the wholesale, retail and banking industry.

\section{Research Framework}

The study is framed around Heckman and Oldham (1976) `s Job characteristics model (JCM) which suggests that positive performance and well-being outcomes (such as employee retention will result from employee experience aspects (work design variables). Therefore the study explores the relationship between work design variables and employee retention. Consequently work design in the context of this study consist of use of own imagination, job design, job description, control of work schedule, challenging work, variety of tasks in job, realistic standards of performance, developmental group assignment, job enrichment and freedom of judgement (Bergh \& Theron, 2012).

The study adopted Coetzee and Schreuder (2012)'s conception of employee retention to refer to initiatives taken by management to keep employees from leaving the organization, such as rewarding employees for performing their jobs effectively; ensuring harmonious working relations between employees and managers; and maintaining a safe, healthy work environment. The variables identified in Coetzee and Schreuder (2012) are construed in our model to relate to work design variables as identified. Therefore the theoretical model for this study is constructed to depict the relationship between work design variables and employee retention as shown in figure 1.

Figure1: Schematic Diagram of the Research Framework

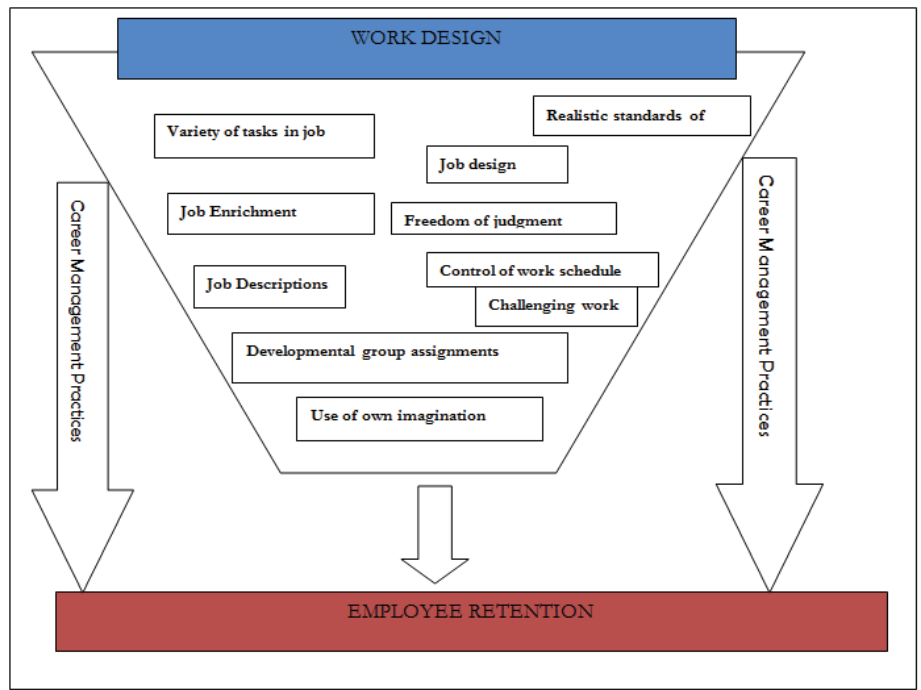




\section{Research Objectives}

- To identify work design variables that contributes to proper employees `retention;

- To investigate the impact of work design on employee retention and ;

- To explain how work should be redesigned to improve employee retention.

- To give recommendations regarding possible work design strategies that can improve employee retention in these mentioned sectors.

\section{Research Hypothesis}

It is important to note that for the purpose of this study only use of own imagination, job design, job description, control of work schedule, challenging work, variety of tasks in job, realistic standards of performance, developmental group assignment, job enrichment and freedom of judgement are construed as work design variables. Therefore the hypothesis formulated for this study is stated as:

$H_{0}$ : There is no significant relationship between work design variables and employees' retention.

$H_{1}$ : There is a significant relationship between work design variables and employees' retention.

\section{Research Methodology}

A quantitative research approach was used. The researchers used a quantitative approach because, as noted by Kabungaidze, Mahlatsana and Ngirande (2013), quantitative research design allows the researcher to answer questions about the relationships between measured variables with the purpose of explaining, predicting and controlling certain phenomena. The study population consisted of both male and female employees from Manufacturing, Wholesale and Retail, Banking and Finance and Others industries in the city of Polokwane, South Africa. The total size of the population was $244(\mathrm{~N}=244)$. Using the RaoSoft sample size calculator, a minimum recommended sample size of 150 respondents was obtained. The respondents were selected using a simple random sampling method.

A self-administered questionnaire was designed using existing instruments as well as information which emerged from the literature. The questionnaire consisted of three sections namely the Biographical and occupational data section, work design variables section and employee retention variables. The Biographical and Occupational Data Questionnaire was constructed by the researchers to tap information relating to certain key biographical and occupational variables relating to the respondents such as age, gender, educational qualifications and type of industry. This information was used mainly for a description of the sample.

Work design variables were identified from literature and a 5-point likert scale was designed by the researchers. Responses to each of the10 items were rated with anchors labelled: $1=$ strongly disagree, $2=$ disagree, $3=$ neither agree nor disagree, 4 = agree, 5= strongly agree. The reliability was tested using the Cronbach Alpha coefficient and a coefficient of 0.74 was achieved, hence the reliability of the instrument can be assumed based on Cooper and Schindler (2008)'s argument that any coefficient above 0.70 implies reliability of the instrument.

Items on employee retention were adopted from the intention to leave questionnaire developed by Cowin (2002). Responses to each of the six items were rated using a 5-point Likert scale with anchors labelled: $1=$ strongly disagree, 2 = disagree, 3 = neither agree nor disagree, $4=$ agree, $5=$ strongly agree. The alpha coefficient for this six-item scale has been 0.96 in previous studies.

In administering the questionnaire, the following procedure was followed:

- The researchers personally requested the Human Resource Director of each industry for permission to distribute the copies of the questionnaire. Questionnaire distribution was done in such a way as to cause no disturbance to work performance.

- The researchers distributed the questionnaire to the respondents during breaks (e.g. lunch time) and also ask the respondents to deposit completed questionnaires in a locked box located in the Human Resource Department where they will be collected after two weeks. A covering letter assuring the prospective respondents of anonymity and confidentiality was accompanying the questionnaire. This covering letter also informs the prospective respondent what the study was about and ask him/her to respond to the questionnaire voluntarily.

The returned questionnaires were inspected to determine their level of acceptability. They were coded. The data was transferred to an Excel sheet. A statistical computer package, Statistics Package for Social Sciences (SPSS) version 
20.0, was used to process the results. Descriptive statistics (e.g. means and standard deviations) were used to describe the data in summary form. Pearson product-moment correlation coefficient was used to measure the relationships between the variables, i.e. between work design and employee retention). Regression analysis was also being carried out to assess the relative contribution of the independent variables to the dependent variable.

\section{Results and Discussion}

This section presents a summary of the findings of the study, whose primary objectives is to investigate the impact of work design on employee retention. This section will begin by presenting the demographic statistics of the respondents. This will be followed by the results on work design variables. Results of the correlations analysis will then be followed by the results of the regression analysis. It is important to note that for the sake of brevity; only outstanding finding will be discussed in detail.

\subsection{Descriptive statistics}

\subsubsection{Response rate}

A hundred and fifty (150) questionnaires were distributed to randomly selected respondents. Out of the hundred and fifty (150) distributed, a hundred and sixteen (116) usable questionnaires were returned. This indicated that a response rate of $77.3 \%$ was achieved. This was considered sufficient enough to continue with the analysis of the data. This is in line with Bryman and Bell (2011:234) who posit that response rates above 60\% are acceptable in business research.

\subsection{Demographic Statistics}

Table 1 presents the demographics statistics of the sample. Majority of the respondents, $58.62 \%$ were females while $41.38 \%$ were males. This could be aligned to the population statistics of South Africa where females constitute the greater portion (52\%) of the population. In terms of the age, $44.83 \%$ of the respondents were in the age group 36-45 years, followed by the age group 21-35 years with $27.59 \%$ respondents. This shows that the samples comprised of mainly the youth and the middle ages and these are the age groups were labour mobility is highly pronounced (Andersen et al., 2008).

Table 1: Descriptive statistics

\begin{tabular}{|c|c|c|}
\hline \multicolumn{2}{|c|}{ Variable } & $\begin{array}{l}\text { Frequencies (\%) } \\
\qquad \mathrm{N}=116\end{array}$ \\
\hline \multirow[t]{2}{*}{ Gender } & Male & 41.38 \\
\hline & Female & 58.62 \\
\hline \multirow[t]{6}{*}{ Age } & $>20$ years & 3.44 \\
\hline & 21-35 years & 27.59 \\
\hline & $36-45$ years & 44.83 \\
\hline & $46-55$ years & 15.52 \\
\hline & $56-65$ years & 8.62 \\
\hline & $<65$ years & 0.00 \\
\hline \multirow[t]{4}{*}{ Educational Qualifications } & Matric Certificate & 25.86 \\
\hline & Diploma & 27.59 \\
\hline & Degree & 35.34 \\
\hline & Post Graduate degree & 11.21 \\
\hline \multirow[t]{4}{*}{ Type of Industry } & Manufacturing & 18.97 \\
\hline & Wholesale and Retail & 40.52 \\
\hline & Banking and Finance & 33.62 \\
\hline & Others & 6.89 \\
\hline
\end{tabular}


In terms of the educational levels of the respondents the majority of the respondents (35.35\%) had a bachelors' degree. Respondents with matric certificates and diplomas were $25.86 \%$ and $27.59 \%$ of the sample, respectively. Respondents with a postgraduate certificate (11.21\%) constituted the lowest portion of the sample. With respect to type of industries, the wholesale and Retail industry (40.52\%) constituted the majority of the respondents. This was followed by the banking and finance industry with $33.62 \%$. The manufacturing industry and other industries were $18.97 \%$ and $6.89 \%$ respectively. The simple randomly sampling technique was used in selecting the respondents; therefore the sample may be regarded as representative of the population under study (Bryman \& Bell, 2011).

\subsection{Work Design Variables}

Ten (10) work design related variables were identified for empirical investigation from the literature review. The results of the empirical investigation are presented in Table 2.

Table 2: Work Design Variables: Frequencies

\begin{tabular}{|c|c|c|c|c|c|}
\hline & $\% \mathbf{S A}$ & $\% A$ & $\% U$ & \%D & $\%$ SD \\
\hline \multicolumn{6}{|l|}{ Use of own imagination } \\
\hline My work structure allows me to use my imagination & 17.24 & 50.86 & 13.79 & 12.07 & 6.03 \\
\hline \multicolumn{6}{|l|}{ Variety of tasks in job } \\
\hline Adequate variety of duties in my work & 13.79 & 44.83 & 15.52 & 16.38 & 9.48 \\
\hline \multicolumn{6}{|l|}{ Realistic standards of performance } \\
\hline Standards of performance for my work are realistic & 16.67 & 52.63 & 17.54 & 8.77 & 4.39 \\
\hline \multicolumn{6}{|l|}{ Job Enrichment } \\
\hline Job Enrichment & 7.08 & 35.40 & 16.81 & 30.09 & 10.62 \\
\hline \multicolumn{6}{|l|}{ Job design } \\
\hline Career focused job designs & 8.77 & 44.74 & 24.56 & 14.91 & 7.02 \\
\hline \multicolumn{6}{|l|}{ Control of work schedule } \\
\hline Control of work schedule & 7.89 & 55.26 & 15.79 & 14.91 & 6.14 \\
\hline \multicolumn{6}{|l|}{ Freedom of judgment } \\
\hline Freedom of judgment & 11.40 & 58.77 & 9.65 & 15.79 & 4.39 \\
\hline \multicolumn{6}{|l|}{ Job Descriptions } \\
\hline Job Descriptions & 13.16 & 50.88 & 21.05 & 10.53 & 4.39 \\
\hline \multicolumn{6}{|l|}{ Developmental group assignments } \\
\hline Developmental group assignments & 7.76 & 38.79 & 29.31 & 18.10 & 6.03 \\
\hline \multicolumn{6}{|l|}{ Challenging work } \\
\hline Challenging work & 19.47 & 41.59 & 13.27 & 15.93 & 9.73 \\
\hline
\end{tabular}

Key: SA=Strongly agree; A=Agree; U=Uncertain; D=Disagree; SD=Strongly Disagree

\subsection{Use of own imagination}

The majority of the respondents, $68.10 \%$ (i.e $17.24 \%$ SA plus $50.86 \% \mathrm{~A}$ ) agreed that their work allows them to use their own imagination. Only $18.10 \%$ of the respondents were of the view that their work does not allow them to use their own imagination, while $13.79 \%$ were not sure. Employees, especially knowledge workers, need to do work that will allow them to think outside the box. The findings of the study show that employees were generally content with the way their jobs allow them to use their own imagination.

\subsection{Variety of tasks in job}

In statement Eight "I am satisfied with the variety of tasks in my work", the responses show that sixteen (13.79\%) respondents strongly agreed and fifty two (44.83\%) agreed with the statement. Eighteen (15.52\%) were uncertain, while nineteen (16.38\%) disagreed and eleven (9.48\%) strongly disagreed. Variety of tasks and duties is a very important contributor to work satisfaction and consequently retention. The responses show that most respondents were satisfied with the variety of tasks in their work, which implies that organizations are doing well in terms of work structuring and providing work that requires employees to be engaged in different tasks.

The findings are supported by Kochanski and Ledford`s (2001) survey which affirms that variety of tasks yield 
more significant predictors of retention than any other type of reward, followed by training opportunities and an employee`s relationship with his or her supervisor.

\subsection{Realistic standards of performance}

For statement number nine "Standards of performance for my work are realistic", the responses show that nineteen (16.67\%) strongly agreed with the statement and sixty (52.63\%) also agreed with it. Twenty (17.54\%) were uncertain and, fifteen (13.16\%) disagreed with the statement. Performance standards serve as a motivator in terms of the targets and objectives that employees should strive to achieve. When set with the employees' full participation, performance standards play a crucial role in encouraging employees to remain with an organization. The results show that employees were satisfied with the performance standards in their organizations.

\subsection{Job Enrichment}

Job enrichment is the vertical loading off an employee's job to make it more challenging, interesting and to provide opportunities for responsibility, growth and recognition (Riggio, 2009). In response to the statement on the involvement of employees in job enrichment and enlargement, forty eight $(42.48 \%)$ respondents agreed with the statement, while nineteen (16.81\%) were uncertain and forty six (40.71\%) disagreed with it. The results reveal a small margin between those who agreed and those who disagreed. However, considering the responses on other factors such as job sculpting, control of work schedule and variety of tasks in job, most respondents were satisfied with them. It can therefore be recommended that organizations be more open about these exercises to employees and get their suggestions to minimize uncertainty.

According to Taylor (2005) job enrichment involves raising the level of responsibility associated with a particular job by allowing employees a greater voice in the planning, execution, and evaluation of their own activities. Although similar to job enrichment, job enlargement does not raise the level of responsibility associated with the work, but rather allows the employee take on additional, varied tasks in an effort to make them feel that they are more valuable members of the organization. One study of enlarged jobs found that that they led to greater employee satisfaction, improved employee initiatives which in turn result in employee retention than those of persons in non-enlarged jobs (Riggio, 2009).

\subsection{Job Design}

For statement Eleven "Job sculpting /design practices are complementary to my career life interests" Sixty one (53.51\%) agreed with the statement while twenty eight (24.56\%) were uncertain. Twenty five (21.93\%) disagreed and two did not respond to the statement. Well-designed jobs determine employees' satisfaction in relation to their deeply embedded life interests. Deeply embedded life interests do not determine what people are good at but rather drive what kind of activities make them happy. The results show that most respondents were satisfied with their work structures. The findings are supported by Kochanski and Ledford's (2001) survey which affirms that there is a signicant relationship between the way a job is designed and worker

\subsection{Control of work schedule}

In response to statement Twelve, "I have adequate control of my work schedule", Nine (7.89\%) strongly agreed and sixty three (55.26\%) agreed with the statement. Eighteen (15.79\%) were rather uncertain of the degree of control they had over their work. Seventeen (14.91\%) disagreed and seven (6.14\%) strongly disagreed with the statement. Rather than being slaves of their work, employees want to have control over the activities of their work. The results show that the majority of respondents were content with the control they had over their work activities. I support of this, in their findings, Hurd, Barcelona, and Meldrum (2008) pointed out that effective use of extrinsic rewards such as control of work schedules, can increase an employees job satisfaction and in turn increase his/her desire to continue being part of the organization.

\subsection{Freedom of judgment}

As to whether employees were at liberty to use their own judgment when performing duties, eighty (70.17\%) respondents 
agreed with the statement while eleven (9.65\%) were uncertain. Twenty three $(20.18 \%)$ disagreed with the statement. The results clearly indicate that employees were content with the amount of autonomy they have in their organizations. The results are supported by Patriota (2009) who pointed out that employees are much willing to stay with the organization when they are allowed to have significant autonomy and control over their work.

\subsection{Job Descriptions}

Statement fourteen, "Jobs are explicitly described to make employees aware of the skills and performance requirements of each job", seventy three (65.04\%) respondents felt that their jobs were indeed properly described while twenty four (21.05\%) were uncertain. Seventeen (14.92\%) disagreed with the statement. Job descriptions eliminate role ambiguity, which can cause stress, and, state precisely what is expected of an individual. Job descriptions also enable employees to understand skills requirements for different positions. This acts as a guide for employees in skills acquisition and career planning. The results show that respondents were content with the descriptions of their jobs in their organizations. In support of this, Ruth and Media (2013) confirms that a clear job description is a reliable predictor of employee retention in any organization.

\subsection{Developmental group assignments}

In response to statement fifteen "Individual and group assignments are developmental", nine (7.76\%) respondents strongly agreed and forty five (38.79\%) agreed with the statement. Thirty four (29.31\%) were uncertain while twenty one (18.10\%) disagreed and seven (6.03\%) strongly disagreed with the statement. Employees use assignments to improve their performance, share and gain information and knowledge with other group members. Considering the results, the uncertainty and discarding of the statement by respondents may be due to lack of explanation about the purpose of group assignments to employees or by poor selection of assignment candidates by managers or supervisors. However, a substantial proportion of respondents were content with group assignments.

\subsection{Challenging work}

For statement seventeen "I am satisfied with the extent to which my job presents challenging work", sixty nine (61.06\%) respondents agreed with the statement while fifteen (13.27\%) were uncertain about whether they get any challenge from their work. Twenty nine $(25.66 \%)$ respondents disagreed with the statement. The result shows that the majority of employees were content with the challenge they get from their work. Providing challenging work is very important in retaining workers. The results show that organizations were doing a good job in terms of providing their employees with challenging work.

\section{Correlation Analysis}

The results of the study yields a statistically significant positive correlations with use of own imagination and variety of task in a job $(r=0.723$, sig. $=0.000)$; realistic standards of performance $(r=0.374 ;$ sig. $=0.000)$; job enrichment $(r=0.309$, sig. $=0.004)$; job design $(r=0.357$, sig. $=0.001)$ as well as control of work schedule $(r=0.246$, sig. $=0.023)$. The findings of this research indicate that a realistic of standards of performance will increase an employees' job fulfilment/stimulation and as a result this will lead to employee retention. This is supported by the Insync Survey (2012) `s retention review results which revealed that people leave primarily because of the job itself (51\%). Either they're not satisfied, they want more career and professional development opportunities, or the level of challenge (whether too high or low) did not suit them or at times they do not have any control over their work as well as their work schedule.

Variety of task in a job showed statistically significant positive correlation with realistic standards of performance $(r=0,347$, sig. $=0.001)$; job enrichment $(r=0.438$, sig. $=0.000)$; job design $(r=0.330$, sig. $=0.002)$ as well as control of work schedule $(r=0.227$, sig. $=0.037)$.

Realistic standards of performance yielded statistically significant positive correlations with job enrichment $(r=0.361$, sig. $=0.001)$; job design $(r=0.493$, sig. $=0.000)$; control of work schedule $(r=0.404$, sig. $=0.000)$; freedom of judgement $(r=0.298$, sig. $=0.006)$ as well as job descriptions $(r=0.428$, sig. $=0.000)$. The results are supported by various studies which revealed that employees performing enriched jobs usually experience lower absenteeism and turnover. In turn this will result in improved employee retention (Griffith, Horn, \& Gaertner, 2000; Rentsch \& Steel, 1998; and Spector 
\& Jex, 1991). Research consistently demonstrates a relationship between job enrichment and control of work (Judge, 2003; Judge, Parker, Colbert, Heller, \& llies, 2002). Along with higher work control and freedom of judgement, employees performing enriched jobs usually experience higher job satisfaction and employee retention (Griffith, Horn, \& Gaertner, 2000).

Job enrichment showed statistically significant positive correlation with job design $(r=0.308$, sig. $=0.004)$ as well as freedom of judgement $(r=0.269$, sig. $=0.013)$. Statistically significant negative correlations were found between job enrichment and developmental group assignments $(r=-0.282$, sig. $=0.009)$. In this case, the more group developmental assignments are given to employees, the less they fell enriched in their jobs. Research findings showed that those who receive fewer groups developmental assignments in their job feel more enriched in their job, are more committed to their organization and have higher levels of job satisfaction, according to a study of South African workers (Orpen, 2001).

Job design showed statistically significant positive correlations with control of work schedule $(r=0.330$, sig. $=0.002)$; freedom of judgement $(r=0.216$, sig. $=0.047)$ as well as job descriptions $(r=0.417$, sig. $=0.000)$. In support of these findings, a study by Batt and Valcour (2001) also found that flexible scheduling practices, freedom of judgement as well as a clear job description were all associated with lower turnover intentions.

Statistically significant positive correlations were found between job descriptions and control of work schedule $(r=0.405$, sig. $=0.000)$. Job descriptions also showed statistically significant positive correlations with freedom of judgement $(r=0.278$, sig. $=0.010)$. This means that the more a job description is clear to an employee, the more one can have control over his/her work schedule. This will in turn result in an increased decision-making autonomy.

Challenging work showed statistically significant positive correlations with freedom of judgement $(r=0.276$, sig. $=0.011$ ). The findings of this research indicate that the more challenging the work is, the more an individual is likely to make his or her own decisions in solving problems. These results are consistent with Media and Kokemuller's (2013) research which found that employees are more mentally stimulated when they take on authoritative, decision-making roles. This keeps them mentally focused on their tasks and the objectives of the company. Also, ambitious employees are more likely to stick with an employer if they are trusted to perform higher level duties.

Table 3: Correlation Analysis

\begin{tabular}{|c|c|c|c|c|c|c|c|c|c|c|c|}
\hline \multicolumn{12}{|c|}{ Correlations } \\
\hline & & $\begin{array}{l}\text { Use of own } \\
\text { imagination }\end{array}$ & $\begin{array}{c}\begin{array}{c}\text { Variety of } \\
\text { tasks in } \\
\text { job }\end{array} \\
\end{array}$ & $\begin{array}{c}\text { Realistic } \\
\text { standards of } \\
\text { performance }\end{array}$ & $\begin{array}{c}\text { Job } \\
\text { Enrichment }\end{array}$ & $\begin{array}{c}\text { Job } \\
\text { design }\end{array}$ & $\begin{array}{c}\text { Control of } \\
\text { work } \\
\text { schedule }\end{array}$ & $\begin{array}{c}\text { Freedom of } \\
\text { judgment }\end{array}$ & \begin{tabular}{|c|} 
Job \\
Descriptions
\end{tabular} & $\begin{array}{c}\text { Developmental } \\
\text { group assignments }\end{array}$ & $\begin{array}{c}\text { Challenging } \\
\text { work }\end{array}$ \\
\hline \multirow{3}{*}{$\begin{array}{l}\text { Use of own } \\
\text { imagination }\end{array}$} & \begin{tabular}{|c|} 
Pearson \\
Correlation \\
\end{tabular} & 1 & $.723^{* *}$ & $.374^{* *}$ & $.309^{* *}$ & $.357^{* *}$ & $.246^{*}$ & -.050 & $.431^{* *}$ & -.014 & -.089 \\
\hline & \begin{tabular}{|l|}
$\begin{array}{l}\text { Sig. (2- } \\
\text { tailed) }\end{array}$ \\
\end{tabular} & & .000 & .000 & .004 & .001 & .023 & .650 & .000 & .901 & .417 \\
\hline & $\mathrm{N}$ & 106 & 106 & 106 & 106 & 106 & 106 & 106 & 106 & 106 & 106 \\
\hline \multirow{3}{*}{$\begin{array}{c}\text { Variety of tasks in } \\
\text { job }\end{array}$} & \begin{tabular}{|c|} 
Pearson \\
Correlation
\end{tabular} & $.723^{\prime \prime}$ & 1 & $.347^{* *+}$ & $.438^{+* t}$ & $.330^{+* *}$ & $.227^{\star}$ & -.041 & $.379^{*+}$ & -.134 & .007 \\
\hline & \begin{tabular}{|l|} 
Sig. (2- \\
tailed)
\end{tabular} & .000 & & .001 & .000 & .002 & .037 & .708 & .000 & .221 & .950 \\
\hline & $\mathrm{N}$ & 106 & 106 & 106 & 106 & 106 & 106 & 106 & 106 & 106 & 106 \\
\hline \multirow{3}{*}{$\begin{array}{c}\text { Realistic standards } \\
\text { of performance }\end{array}$} & \begin{tabular}{|c|} 
Pearson \\
Correlation \\
\end{tabular} & $.374^{* *}$ & $.347^{+*}$ & 1 & $.361^{* *}$ & $.493^{+* *}$ & $.404^{* *+}$ & $.298^{+*}$ & $.428^{* *+}$ & -.078 & .074 \\
\hline & \begin{tabular}{|l|}
$\begin{array}{l}\text { Sig. (2- } \\
\text { tailed) }\end{array}$ \\
\end{tabular} & .000 & .001 & & .001 & .000 & .000 & .006 & .000 & .476 & .499 \\
\hline & $\mathrm{N}$ & 106 & 106 & 106 & 106 & 106 & 106 & 106 & 106 & 106 & 106 \\
\hline \multirow{3}{*}{ Job Enrichment } & \begin{tabular}{|c|} 
Pearson \\
Correlation
\end{tabular} & $.309^{+* *}$ & $.438^{* *}$ & $.361^{* *}$ & 1 & $.308^{+* x}$ & .119 & $.269^{*}$ & .182 & $-282^{* * *}$ & -.002 \\
\hline & \begin{tabular}{|l|} 
Sig. (2- \\
tailed) \\
\end{tabular} & .004 & .000 & .001 & & .004 & .280 & .013 & .095 & .009 & .986 \\
\hline & $\mathrm{N}$ & 106 & 106 & 106 & 106 & 106 & 106 & 106 & 106 & 106 & 106 \\
\hline \multirow{3}{*}{ Job design } & \begin{tabular}{|c|} 
Pearson \\
Correlation
\end{tabular} & $.357^{* *}$ & $.330^{* *}$ & $.493^{* *}$ & $.308^{* *}$ & 1 & $.330^{* * *}$ & $.216^{*}$ & $.417^{\text {t* }}$ & -.059 & .008 \\
\hline & \begin{tabular}{|l|}
$\begin{array}{l}\text { Sig. (2- } \\
\text { tailed) }\end{array}$ \\
\end{tabular} & .001 & .002 & .000 & .004 & & .002 & .047 & .000 & .592 & .940 \\
\hline & $\mathrm{N}$ & 106 & 106 & 106 & 106 & 106 & 106 & 106 & 106 & 106 & 106 \\
\hline \multirow{3}{*}{$\begin{array}{l}\text { Control of work } \\
\text { schedule }\end{array}$} & \begin{tabular}{|c|} 
Pearson \\
Correlation
\end{tabular} & $.246^{*}$ & $.227^{*}$ & $.404^{* *}$ & .119 & $.330^{* *}$ & 1 & .095 & $.405^{\text {t* }}$ & -.046 & .002 \\
\hline & \begin{tabular}{|l|}
$\begin{array}{l}\text { Sig. (2- } \\
\text { tailed) }\end{array}$ \\
\end{tabular} & .023 & .037 & .000 & .280 & .002 & & .385 & .000 & .674 & .984 \\
\hline & $\mathrm{N}$ & 106 & 106 & 106 & 106 & 106 & 106 & 106 & 106 & 106 & 106 \\
\hline \multirow{3}{*}{$\begin{array}{c}\text { Freedom of } \\
\text { judgment }\end{array}$} & \begin{tabular}{|c|} 
Pearson \\
Correlation
\end{tabular} & -.050 & -.041 & $.298^{* *}$ & $.269^{*}$ & $.216^{*}$ & .095 & 1 & $.278^{+*+}$ & -.004 & $.276^{*}$ \\
\hline & $\begin{array}{l}\text { Sig. (2- } \\
\text { tailed) }\end{array}$ & .650 & .708 & .006 & .013 & .047 & .385 & & .010 & .971 & .011 \\
\hline & $\mathrm{N}$ & 106 & 106 & 106 & 106 & 106 & 106 & 106 & 106 & 106 & 106 \\
\hline
\end{tabular}




\begin{tabular}{|c|c|c|c|c|c|c|c|c|c|c|c|}
\hline \multirow{3}{*}{ Job Descriptions } & \begin{tabular}{|c|} 
Pearson \\
Correlation
\end{tabular} & $.431^{* *}$ & $.379^{* *}$ & $.428^{*}$ & .182 & $.417^{*}$ & $.405^{* *}$ & $.278^{* *}$ & 1 & -.182 & .050 \\
\hline & \begin{tabular}{|l|} 
Sig. (2- \\
tailed)
\end{tabular} & .000 & .000 & .000 & .095 & .000 & .000 & .010 & & .096 & .647 \\
\hline & $\mathrm{N}$ & 106 & 106 & 106 & 106 & 106 & 106 & 106 & 106 & 106 & 106 \\
\hline \multirow{3}{*}{$\begin{array}{c}\text { Developmental } \\
\text { group assignments }\end{array}$} & \begin{tabular}{|c|} 
Pearson \\
Correlation \\
\end{tabular} & -.014 & -.134 & -.078 & $-.282^{* *}$ & -.059 & -.046 & -.004 & -182 & 1 & -.003 \\
\hline & \begin{tabular}{|l} 
Sig. (2- \\
tailed)
\end{tabular} & .901 & .221 & .476 & .009 & .592 & .674 & .971 & .096 & & .979 \\
\hline & $N$ & 106 & 106 & 106 & 106 & 106 & 106 & 106 & 106 & 106 & 106 \\
\hline \multirow{3}{*}{ Challenging work } & \begin{tabular}{|c|}
$\begin{array}{c}\text { Pearson } \\
\text { Correlation }\end{array}$ \\
\end{tabular} & -.089 & .007 & .074 & -.002 & .008 & .002 & $.276^{*}$ & .050 & -.003 & 1 \\
\hline & \begin{tabular}{|l} 
Sig. (2- \\
tailed)
\end{tabular} & .417 & .950 & 499 & .986 & .940 & .984 & .011 & .647 & .979 & \\
\hline & $\mathrm{N}$ & 106 & 106 & 106 & 106 & 106 & 106 & 106 & 106 & 106 & 106 \\
\hline
\end{tabular}

\section{Regression Results}

Ordinary least squares regression (OLS) of the work design variables were used to determine the magnitude and direction of effects of these variables on employee retention. The no intercept regression model was used in this analysis because all predictors have no possibility of being equal to zero so much that the intercept would not have any meaningful interpretation. The results of that analysis are shown in Table 4. The model indicates that $64.8 \% \%$ (RSquare $=0.648$ ) variation in employee retention (reten) is explained by the predictor variables. The Durbin-Watson indicates that the assumption of independent error is tenable since for these data the figure is 1.647 and is close to 2 (Durbin \& Watson, 1951). No incidences of multicollinearity are observed in the model since none of the variance inflation factors (VIF) are close to or greater than 5 . The analysis of variance table shows that the variables in the model have a statistically significant effect on educational outcomes ( $F=13.638$; Sig. $=0.000$ ).

Table 4: Regression Analysis

Model Summaryb

\begin{tabular}{|c|c|c|c|c|c|}
\hline Model & $\mathrm{R}$ & $\mathrm{R}$ Square & Adjusted R Square & Std. Error of the Estimate & Durbin-Watson \\
\hline 1 & $.805^{\mathrm{a}}$ & .648 & .601 & .845 & 1.647 \\
\hline
\end{tabular}

a. Predictors: (Constant), OnIm, Vtsk, Rstd, Jenr, Jdsn, Cwrk, Fjud, Jdes, Dgas, Chrk

b. Dependent Variable:Reten

ANOVA

\begin{tabular}{|cc|c|c|c|c|c|}
\hline & Model & Sum of Squares & df & Mean Square & F & Sig. \\
\hline \multirow{2}{*}{1} & Regression & 97.360 & 10 & 9.736 & 13.638 & $.000^{\mathrm{b}}$ \\
& Residual & 52.828 & 74 & .714 & & \\
& Total & 150.188 & 84 & & & \\
\hline
\end{tabular}

a. Dependent Variable: Reten

b. Predictors: (Constant), OnIm, Vtsk, Rstd, Jenr, Jdsn, Cwrk, Fjud, Jdes, Dgas, Chrk

Coefficients $^{\mathrm{a}}$

\begin{tabular}{|c|c|c|c|c|c|c|c|}
\hline \multirow{2}{*}{ Model } & \multicolumn{2}{|c|}{ Unstandardized Coefficients } & Standardized Coefficients & \multirow{2}{*}{$\mathrm{t}$} & \multicolumn{2}{|c|}{ Sig. } & \multicolumn{2}{|c|}{ Collinearity Statistics } \\
\cline { 2 - 4 } \cline { 6 - 7 } & $\mathrm{B}$ & Std. Error & Beta & & & Tolerance & VIF \\
\hline (Constant) & .352 & .533 & & .660 & .511 & & \\
\hline Onlm & .329 & .108 & .303 & 3.055 & .003 & .482 & 2.074 \\
Vtsk & .621 & .110 & .558 & 5.625 & .000 & .483 & 2.071 \\
Rstd & .308 & .129 & .238 & 2.387 & .020 & .479 & 2.089 \\
Jenr & .203 & .162 & .165 & 1.249 & .021 & .271 & 3.685 \\
Jdsn & .052 & .175 & .037 & .297 & .768 & .305 & 3.279 \\
Cwrk & .040 & .128 & .034 & .310 & .758 & .385 & 2.600 \\
Fjud & .100 & .151 & .086 & 2.663 & .019 & .283 & 3.528
\end{tabular}




\begin{tabular}{|l|l|l|l|l|l|l|l|}
\hline Jdes & -.103 & .124 & -.083 & -.827 & .411 & .475 & 2.104 \\
Dgas & .030 & .153 & .023 & .195 & .846 & .332 & 3.014 \\
Chrk & -.082 & .085 & -.080 & -.962 & .339 & .680 & 1.471 \\
\hline
\end{tabular}

a. Dependent Variable: Reten

From the regression results presented in Table 4, it can be noted that not all variables have a statistically significant effect on employee retention (reten). Statistically significant effects are observed on use of own imagination (OnIm) $(\mathrm{t}=3.055$, sig. $=.003)$; variety of tasks in job (Vtsk) $(\mathrm{t}=5.625$, sig. $=.000)$; realistic standards of performance (Rstd) $(\mathrm{t}=2.387$, Sig. $=.020)$; job enrichment (Jenr) $(\mathrm{t}=1.249$, sig. $=0.021)$ and freedom of judgement (Fjug) $(\mathrm{t}=2.663$, sig. $=0.019$ ).

All the five variables (Onlm, Vtsk, Rstd, Jenr and Fjud) yield positive Beta coefficients indicating that they result in increases in employee retention. Therefore, at $a=0.05$ level of significance, the study conclude that use of own imagination, variety of tasks in job, realistic standards of performance; job enrichment and freedom of judgement have a positive effect on employee retention. Thus:

$$
\text { reten }=\alpha+\beta_{1} \text { Onlm }+\beta_{2} \text { Vtsk }+\beta_{3} \text { Rstd }+\beta_{4} \text { Jenr }+\beta_{5} \text { Fjud }+E \text {. }
$$

Based on the findings of this study we fail to accept our null hypothesis $\left(\mathrm{H}_{0}\right)$ that there is no significant relationship between work design variables and employees' retention. Therefore this study provide reasonable ground to conclude that work design have a significant positive effect on employee retention.

\section{Conclusion and Recommendations}

The findings of this study set out to explore the work design variables that have favourable impacts on employee retention. Consequently these findings are of great value in providing directions on the discourse to finding solutions to effective career management practices for long term relationship/service between the organisations and their employees. The identified work design variables will not only foster employee retention for its own sake but rather will go a long way is saving organisations substantial amounts in the cost of labour turnover. For the employee, stability, job security and other positive financial, social and psychological are just but a few benefits that can be derived from effective work design variables identified in this study.

Moreover the use of own imagination, variety of tasks in job, realistic standards of performance, job enrichment and freedom of judgement, the variables we found to have statistically significant positive correlations with employee retentions could also be investigated further to establish other benefits that could be derived from these practices. The study therefore recommended further studies to include other career management practices such as...... and their effects on employee retention, employee satisfactions and overall organisational success. Furthermore cost-benefit analysis of implementing these practices could a valuable area for future research.

\section{References}

Andersen, T., Haahr, J. H., Hansen, M.E \& Holm-Pedersen, M. (2008). Job Mobility in the European Union: Optimising its Social and Economic Benefits. Denmark: Danish Technological Institute.

Batt, R., \& Valcour, P.M. (2001). Human Resource Practices as Predictors of Work-Family Outcomes and Employee Turnover. Cornell University.

Bergh, Z.C., \& Theron, A. L. (2012). Psychology in the work context. (4th edn.).Cape Town Oxford University Press Southern Africa Pty Ltd.

Bryman, A., \& Bell, E. (2011). Business Research Methods. (3rd edn.). Oxford University Press: Oxford.

Cappelli, P. (2000). "Market-Driven Approach to Retaining Talent". Harvard Business Review, 79(1), 103-112.

Coetzee. \& Schreuder, D. (2012). Personnel Psychology: An applied perspective. Cape Town: Oxford University Press.

Cole, C. (2000). Building loyalty. Workforce, 79, 42-47.

Cooper, D. R., \& Schindler, P.S. (2008). Business Research Methods. (10th edn.). Mcgraw-Hill Higher Education.

Cooper- Hakim, A., \& Viswesvaran, C. (2005). The Construct of Work Commitment: Testing an Integrative Framework. Psychological Bulletin, 131(2), 241-259.

Cowin, L. (2002). The effects of nurses' job satisfaction on retention. An Australian perspective. Jona, 32(5), 283-29.

Durbin, J., \& Watson, G. S. (1951). "Testing for Serial Correlation in Least Squares Regression, II". Biometrika 38 (1-2): 159-179.

Erasmus, B.J., Loedolff, P.V.Z., Mda, T.V., \& Nel, P.S. (2013). Managing training and development. Oxford University press: Southern 
Africa.

Gialuisi, O. (2012). An exploratory investigation into Voluntary Employee Turnover and Retention Practices in the Small Business Sector. Edith Cowan University.

Griffeth, R. W., Horn, P. W., \& Gaertner, S. (2000). A meta-analysis of antecedents and correlates of employee turnover: Update, moderator tests, and research implications for the next millennium. Journal of Management, 26(3), 463-488.

Hackman, J. R., \&. Oldham, G. R. (1976). "Motivation through the design of work: Test of a theory." Organizational Behavior and Human Performance, 16, 250-279.

Huws, U., \& Ramioul, M. (2006). Globalisation and the restructuring of value chains. In Huws, U (Ed). The transformation of work in a global knowledge economy: towards a conceptual framework.[online] available at http://worksproject.be: Accessed 11 October 2013.

Hurd, A. R, Barcelona, R. J., \& Meldrum, J.T. (2008). Recreation managers can use rewards to improve employee motivation, retention. Human Kinetics Publishers.

Judge, T. A. (2003). Promote job satisfaction through mental challenge. In E. A. Locke (Ed.), Handbook of principles of organizational behavior.(Hoboken, NJ: Wiley-Blackwell.

Judge, T. A., Parker, S. K., Colbert, A. E., Heller, D., \& llies, R. (2002). A cross-cultural review. In N. Anderson \& D. S. Ones (Eds.), Handbook of industrial, work and organizational psychology. 2, 25-52.

Kabungaidze, T., Mahlatshana, N., \& Ngirande, H. (2013). The impact of job satisfaction and some demographic variables on employee turnover intentions. International Journal of Business Administration, 4(1): 53-65.

Kalleberg, A. L. (2003). Flexible Firms and Labor Market Segmentation: Effects of Workplace Restructuring on Jobs and Workers. Work and Occupations, 30(2):154-175.

Mam, H. A., \& Mace, A. (2010). Impact of job design on employees' performance (with special reference to school teachers in the Kalmunai zone). University of Kelaniya, Sri Langa.

Maree, J. G. (2012). A guided met-reflection theory of career counselling: A case study. South African journal of Higher Education, 26(4): 670-690.

Media, D., \& Kokemuller, N. (2013). What Is the Meaning of Job Enrichment? Houston Chronicle.

Mostafa, K.G. (2012). The impact of job satisfaction on employee retention at an independent television LTD. Independent University Bangladesh.

Orpen, C. (2001). The Effects of Job Enrichment on Employee Satisfaction, Motivation, Involvement, and Performance: A Field Experiment. Human Relations, 32: 189-217.

Patriota, D. (2009). Employee retention: An integrative view of supportive Human Resource Practices and Perceived Organizational support. Masters dissertation: Uppsala University.

Redman, T. \& Wilkinson. (2009). Contemporary Human Resources Management (2nd edn).London: Prentice Hall.

Rentsch, J. R., \& Steel, R. P. (1998). Testing the durability of job characteristics as predictors of absenteeism over a six-year period. Personnel Psychology, 51(1), 165-190.

Riggio, R. E. (2009).Introduction to industrial /Organisational psychology (5 $5^{\text {th }}$ edn.).Pearson.

Riyasa. A. R. (2008). 'Impact of job design on employee's satisfaction in Daya Garments. (Unpublished Dissertation, South Eastern University of Sri Lanka).

Ruth, M. \& Media, D. (2013). Employee Retention \& Satisfaction. Houston Chronicle.

Spector, P. E., \& Jex, S. M. (1991). Relations of job characteristics from multiple data sources with employee affect, absence, turnover intentions, and health. Journal of Applied Psychology, 76, 46-53.

Taylor, S. E. (2006). Health Psychology (6th edn.). New York: McGraw- Hill.

The (2012) Insync Surveys Retention Review. How to reduce turnover and retain your high performing employees. Accessed from http://www.insyncsurveys.com.au

Ziegler, R. (2001). The high performance work force: separating the digital economy's winners from losers. In the battle for retention accentures study. Accenture. 